\title{
A unique system of graduate management training for the working executive - an evaluation of success
}

\author{
Georg Marais
}

The UNISA School of Business Leadership offers a unique Master's degree in Business Leadership, training working executives in all parts of southern Africa by teletuition. An overview is given of the methodology and the activity span of the SBL. The article also covers a survey of MBL graduates, analyzing their career history including topics such as original academic background, current management and income levels, age, occupational mobility both intra- and inter-organizationally, years of experience before and after MBL studies, and academic performance in the MBL. The achievements of, and trends among MBL graduates are compared with information available on MBA graduates from two other South African business schools, and with similar research in the United States and Britain.

S. Afr. J. Bus Mgmt 1979, 10:77 - 86

Die Skool vir Bedryfsleiding van UNISA bied 'n unieke Meestersgraad in Bedrysleiding aan, wat werkende bestuurders in alle dele van Suider-Afrika deur afstands-onderrig oplei. 'n Oorsig word gegee van die metodologie en die aktiwiteitswydte van die SBL. die artikel dek ook 'n opname onder MBL-gegradueerdes, en ontleed hulle loopbaangeskiedenis aan die hand van aspekte soos oorspronklike akademiese agtergrond, huidige bestuurs- en inkomstevlakke, ouderdom, jare ervaring vóór en ná MBL-studies, beroepsbeweeglikheid sowel binne as tussen organisasies, en akademiese prestasie in die MBL. Die prestasies van, en neigings onder MBL-graduandi word vergelyk met beskikbare inligting oor MBA-graduandi van twee ander Suid-

Afrikaanse sakeskole, en met soortgelyke navorsing in die Verenigde State en Brittanje.

S.Afr. Tydskr. Bedryfsl. 1979, 10:77-86
Eleven years ago the first 30 students received their Master's degree in Business Leadership (MBL) at the University of South Africa - after completion of a four year part-time study programme, designed for experienced business people, using teletuition as its main teaching technique. The time is ripe to review the first post-graduate management training programme by teletuition in the world and to reveal its strengths and weaknesses.

In the United States and Europe graduate management training has up to now been of fered only at residential business schools where the case study technique, or the lecture system, or combinations or variations of these methods are the main teaching modes. In these countries, graduate management training by teletuition is usually not seen as a possible solution for training the working executive because it is regarded as being similar to correspondence training. Correspondence training is rated highly in the transfer of knowledge to the independent learner but not as the best technique or mode to transfer knowledge, skills and attitudes and to assist the learner to integrate and implement these three basic elements in the practical situation.

In contrast with the general view of teletuition, management training for the MBL is a combination of correspondence training and localized or classroom training. It can best be described as decentralized classroom teaching attained through a system of study groups or learning cells formed in different locations, and linked by correspondence and regular study schools at a central location. This teaching system is the ideal system to bring management training to the working executive who cannot leave his or her job for full-time training or attend evening classes at a city university. This system has the flexibility of being able to fit into the working executive's normal work programme.

This paper on a survey among SBL graduates is divided into three sections - a short description of the School of Business Leadership (SBL) with the emphasis on its unique teaching methods; a profile of MBL alumni; and alumni's perception of the business school's image. 
The structure of the business school and its teaching methodology

The School of Business Leadership was founded in 1963 as a sub-section of the Department of Business Economics of the University of South Africa and in 1964 the first students registered for the MBL. The subsection, comprising the present director (the author) and a secretary, was instituted to initiate a graduate degree or diploma in management for the working executive who found it impossible to attend a full-time or part-time (evening classes) MBA programme at one of the residential universities in South Africa.

At present the School of Business Leadership is a department of the Faculty of Commerce and Administration of the University of South Africa, a governmentsubsidized university concentrating on correspondence teaching.

\section{The largest business school in South Africa}

In 1979 the University of South Africa had 55443 students of all races. According to Table 1 the School of Business Leadership is the largest business school in South Africa. Its number of MBL graduates per annum

Table 1 The number of MBA and MBL graduates at South African universities in 1975, 1976, 1977 and 1978

Business schools

South Africa (SBL)

4 year programme - teletuition

Cape Town

13 month plus programme - fulltime

Witwatersrand

15 month programme - full-time

Pretoria

2 year programme - evening classes

Stellenbosch

13 month plus programme - full-time

Potchefstroom

3 year programme - weekends

Total

$\begin{array}{llll}230 & 278 & 267 & 284\end{array}$

Source: Department of National Education, 1978.

outnumbers by far that of any of the other five business schools in the country. In 1977 the SBL produced $30 \%$ of the total number of graduates, and in $1979,43 \%$. According to Table 2, on November 30, 1978 the school had 1284 registered students on its eight programmes, 766 of whom were MBL and DBL students, while 518 students were registered for certificate programmes. In addition 1063 people attended 21 seminars offered by the SBL. Converted into student/day units there were 2597 seminar participants in 1978 as some seminars were two days or more in length. In July 1979 the school's alumni totalled five DBL graduates, 647 MBL graduates, 417 Advaned Executive's Programme (AEP) certificate holders, 515 Management Development Programme (MDP) certificate holders and 314 certificate holders of other programmes - a total of 1898 .
Table 2 Registered students at the School of Business Leadership on 30 November 1978

\begin{tabular}{lrc}
\hline \multicolumn{1}{c}{ Academic programme } & $\begin{array}{r}\text { No. of } \\
\text { students }\end{array}$ & $\begin{array}{c}\text { No. of } \\
\text { study groups }\end{array}$ \\
\hline MBL (I, II, III) & 542 & 65 \\
MBL (IV) & 196 & - \\
DBL (doctoral programme) & 28 & - \\
Total & 766 & 65 \\
SBL Board Programmes & & \\
(Certificate courses) & 89 & 13 \\
Advanced Executive's Programme & 211 & 28 \\
Management Development Programme & & \\
Management Development Programme & 62 & 10 \\
for Anglo American Corporation & 28 & 5 \\
Real Estate Programme & & \\
Small Business Administration Pro- & 78 & 8 \\
gramme & 50 & 5 \\
Basic Personnel Programme & 518 & 69 \\
Total & 1284 & 134 \\
\hline Total & & \\
\hline
\end{tabular}

'In MBL (IV) students work on their dissertations, papers and projects and are not organized into study groups, and do not have to attend study schools.

Options are available in most of the eight programmes. The following are available within the structure of the MBL and the MDP: Business Policy (General Management), Manpower Management, Information Management, Financial Institutions and Real Estate, with Mining as an additional specialization in the MDP. In the AEP no options are available and the main emphasis is on Business Policy. The AEP is a 15 -month senior management programme, which has been presented annually since 1970.

All programmes of the SBL are organized into ten modules per annum - five modules per semester. Examinations are taken at the end of each semester. All programmes have a core of general management modules. In the MBL the core constitutes a total of 22 of the 40 modules done over four years.

\section{Three elements of technique}

The unique characteristic of the SBL is its teletuition training technique copsisting of three basic elements namely correspondence, study schools and study groups.

Table 3 gives a summary of the activities of teaching modes of the school handled by $\mathbf{4 6}$ full-time lecturers assisted by 28 administrative and clerical staff and typists. The school also makes use of visiting professors from the United States of America, Canada and Europe, and of local businessmen. Two leading businessmen were professors extraordinary in 1978.

Study groups scattered throughout Southern Africa spend an average of about six hours per week on group assignments. According to Table 2, in 19781060 students were organized into 134 study groups. The 28 doctoral students do not belong to study groups. According to Table 3, study groups in 1978 submitted 1548 group assignments (12 per study group), mainly case studies and field assignments. In total lecturers visited the 
Table 3 Main teaching activities of the School of Business Leadership 1978

\begin{tabular}{lr}
\hline Study group activities & Total \\
No. of group assignments marked, mainly case studies 1548 \\
$\begin{array}{l}\text { No. of visits to study groups } \\
\text { No. of periods spent with groups by lecturers (40 }\end{array}$ & 614 \\
$\quad$ minutes) & 3512 \\
Correspondence activities & \\
$\quad \begin{array}{l}\text { No. of individual assignments marked } \\
\text { No. of final year MBL dissertations and scripts com- }\end{array}$ & 1516 \\
$\quad$ pleted & 2185 \\
$\begin{array}{l}\text { No. of tests marked } \\
\text { No. of examination papers marked }\end{array}$ & 5668 \\
Study school activities & 41 \\
No. of study schools presented & \\
No. of study school lecture periods (40 minutes) & 2323 \\
\hline
\end{tabular}

134 study groups 614 times in 1978 - an average of five times per group; in some programmes once per month and in other programmes every second month. The average number of lecture periods ( 40 minutes) per study group during group visits amounted to 26 per annum.

The correspondence part of the teaching system can be measured by the number of individual assignments submitted, that is 8516 , or an average of eight per student in 1978 , as well as the number of group assignments marked and returned with extensive comments.

The third part of the teaching system is the study schools. Full-time study schools, mostly of a week's duration and totalling between two and five weeks per annum per programme are usually held in Pretoria where the SBL is based. In total 41 were presented in 1978 and an average of 57 lectures were given per study school. It is interesting to note that on average 127 lectures per lecturer were given - a surprisingly high figure when compared with the number of lectures per lecturer in residential universities, which varies between 200 and 250 per annum. This includes the lectures to study groups which are repeated during group visits, depending on the number of study groups in a programme. The number of tests per student (written during study schools) was two and on average five examination papers per student. The statistics of the teaching mode indicate the intensity of study of this unique teaching system.

\section{Profile of students of the SBL in 1978}

The main characteristics of the present student body are that they are mostly in their 30 s, and that they all have business experience. They are located throughout South Africa, Namibia, Swaziland, Botswana and Zimbabwe Rhodesia; work in a large number of organizations and industries and have different academic backgrounds. Students include a growing number of blacks. The number of women students is still very low, although increasing, especially among blacks.

The average age of MBL starters is $\mathbf{3 0}$ and has varied between 30 and 33 since the school's inception. The average age of students doing certificate programmes is 35.
A very important feature of the school's approach is that before a student is accepted for the MBL he or she must have a minimum of three years' business experience, and for the other programmes the requirement varies between three and ten years.

Although there are students in distant places, such as Salisbury (Zimbabwe Rhodesia), Oranjemund (Namibia), Phalaborwa (Northern Transvaal), Durban, Cape Town, Sishen (Northern Cape), more than $50 \%$ of the students are from the Witwatersrand area, in or around Johannesburg.

In 1977 the SBL students came from 363 organizations compared with 223 in 1970 . Most SBL students (namely $46 \%$ ) were employed in manufacturing, followed by $12 \%$ in government organizations, $11 \%$ in commerce and $10 \%$ in mining. At present the percentage of MBL students whose tuition fees are paid by their employers varies between 55 to $65 \%$, depending on the year of study. Most of the students on the certificate programmes are financed by their employers and every year the school makes a large number of scholarships available to black students.

Analysis of the academic backgrounds of MBL I students between 1966 and 1978, shows that the proportion of students with a scientific or technical background varied between 50 and $73 \%$ of the total.

Over the years, with the introduction of new and better training methods, the pass rate has increased. The school requires no special admission tests but uses the first year to screen the students. The first year MBL pass rate is just over $60 \%$ and the total pass rate for the school for all registered students about $70 \%$. During the final two years of the MBL both an internal examiner and an external examiner from another university or from the businessworld are used for the evaluation of all papers and dissertations. The pass rate is an indication of the effectiveness of the school's teaching methods, since it compares favourably with average rates for part-time and correspondence studies, and even with those at the residential business schools. In the case of the Witwatersrand and Cape Town business schools the number of students obtaining their degrees as a percentage of registration between 1975 and 1977 was 49 and $86 \%$ respectively.

\section{A profile of the MBL graduate \\ The 1973 and 1978 surveys}

Two surveys were carried out among MBL graduates and AEP certificate holders. The first survey was done in 1973 and the second during late 1977 and early 1978. In 1973, 196 questionnaires were sent to MBL graduates and 149 usable ones were returned. (Forty-two were from final year students.) In the second survey 513 questionnaires were sent to MBL graduates and 304 usable ones were returned. In the case of the AEPs 139 responded out of a total of 357 in the $1977 / 78$ survey. The questionnaires were designed to give the SBL feedback on MBL and AEP graduates with regard to:

- occupational history

- the value and importance of the MBL of AEP course content for the student's current and future career

- the teaching methods employed, and

- the image of the School of Business Leadership.

In Table 4 the most important results concerning the 
Table 4 Main characteristics of MBL graduates between 1968 and 1977 (1978 survey)

\begin{tabular}{|c|c|c|c|c|c|c|c|c|c|}
\hline \multicolumn{2}{|l|}{ Main characteristics } & \multirow[t]{2}{*}{ Total } & \multicolumn{3}{|c|}{ Years since graduation } & \multicolumn{2}{|c|}{ Level } & \multicolumn{2}{|c|}{$\begin{array}{c}\text { Academic } \\
\text { background }\end{array}$} \\
\hline & & & $\begin{array}{c}\text { Group A } \\
\begin{array}{c}1-3 \\
\text { years }\end{array}\end{array}$ & $\begin{array}{c}\text { Group B } \\
\begin{array}{c}4-6 \\
\text { years }\end{array}\end{array}$ & $\begin{array}{c}\text { Group C } \\
7 \text { and } \\
\text { more } \\
\text { years }\end{array}$ & $\begin{array}{c}\text { Executive } \\
\text { and } \\
\text { Managing } \\
\text { Directors }\end{array}$ & Others & Engineers & Others \\
\hline Size of sample & & 304 & 176 & 76 & 52 & 84 & 220 & 171 & 133 \\
\hline $\begin{array}{l}1 \text { Average annual gross income } \\
\text { (including fringe benefits) }\end{array}$ & $\mathbf{R}$ & 21794 & 20491 & 22546 & 25106 & 26404 & 20034 & 21643 & 21989 \\
\hline 2 Senior management level & $\%$ & 62,1 & 59,7 & 64,5 & 67,3 & $90,5^{1}$ & 51,3 & 61,0 & 62,4 \\
\hline 3 Sub-ordinates & No. & 88,0 & 72,8 & 147,9 & 52,4 & 71,0 & 94,6 & $! 02,4$ & 69,7 \\
\hline 4 Afrikaans-speaking ${ }^{2}$ & $\%$ & 43,1 & 39,2 & 46,1 & 51,9 & 35,7 & 45,9 & 41,5 & 45,1 \\
\hline 5 English-speaking & $\%$ & 61,5 & 65,3 & 64,3 & 48,1 & 69,0 & 58,6 & 59,6 & 63,9 \\
\hline 6 Age & years & 39,0 & 37,5 & 39,7 & 43,2 & 38,5 & 39,2 & 38,8 & 39,4 \\
\hline $\begin{array}{l}7 \text { Average mark in final two years of } \\
\text { study }^{3}\end{array}$ & $\%$ & 64,5 & 65,2 & 64,3 & 62,6 & 65,0 & 64,5 & 64,9 & 64,0 \\
\hline $\begin{array}{l}8 \text { Time taken to complete the four } \\
\text { year programme }\end{array}$ & years & 5,3 & 5,4 & 5,8 & 4,2 & 4,7 & 5,5 & 5,0 & 5,7 \\
\hline 9 Line position & $\%$ & 67,4 & 65,3 & 75,0 & 63,5 & 100,0 & 62,7 & 68,4 & 66,2 \\
\hline 10 Years since graduation & & 3,1 & 1,5 & 4,34 & 6,8 & 3,4 & 3,0 & 3,2 & 3,0 \\
\hline $\begin{array}{l}11 \text { Years of experience before register- } \\
\text { ing for the MBL }\end{array}$ & & 10,5 & 10,0 & 10,6 & 11,9 & 9,6 & 10,8 & 9,9 & 11,3 \\
\hline $\begin{array}{l}12 \text { No. of positional changes in same } \\
\text { organization since graduation }\end{array}$ & & 1,82 & 1,73 & 1,88 & 1,96 & 1,89 & 1,78 & 1,80 & 1,82 \\
\hline $\begin{array}{l}13 \text { Respondents who changed to other } \\
\text { organizations since graduation }\end{array}$ & No. & 0,42 & 0,38 & 0,53 & 0,44 & 0,45 & 0,41 & 0,39 & 0,47 \\
\hline
\end{tabular}

${ }^{1}$ This is less than $100 \%$ because eight of the 84 respondents in the category Executive and Managing Directors did not describe themselves as senior managers for several reasons, e.g. because they are owners or directors of firms.

${ }^{2}$ In some cases both languages are spoken at home, thus the total of lines 4 and 5 is more than $100 \%$.

${ }^{3} 65-70 \%$ is equal to $\mathrm{A}-$ and $\mathrm{A}$ in American business schools and $60-65 \%$ is equal to $\mathrm{B}$ and $\mathrm{B}+$.

main characteristics of the MBL graduates who completed studies between 1968 and 1977 are given. For the sake of clarity and because some comparisons are drawn with MBA graduates of other local and overseas business schools, only the results relating to the MBL alumni are discussed in this report.

The results of the survey concerning variables which explain the income levels of MBLs, the mobility of MBL graduates, the profile of MBLs in executive positions and the perception of the business school's image are given. The value and importance of the MBL course content and the SBL's teaching techniques are analyzed in separate articles.

\section{Age and business experience}

According to Table 4 the average age of the MBL respondent in the 1978 survey was 39,0 years. The respondents are divided into three groups: Group A (176 respondents) - graduates who on average completed their studies 1,5 years prior to the survey, with an average age of 37,5 at the time of the survey; Group B (76 respondents) graduates who on average completed their studies 4,3 years previously and with an average age of 39,7 ; and Group C ( 52 respondents) - graduates who on average completed their studies 6,8 years previously with an average age of 42,2 years. These three groups of graduates had an average of 10,5 years of business ex- perience before starting their part-time studies for the MBL, and on average they completed their studies in 5,3 years. It is interesting to note that there was an increase in the average number of years it took the three groups to complete their studies, i.e. from 4,2 years for Group $C$ to 5,4 years for Group A. The reason is partly that the school had built up a backlog of students who did not complete their dissertations in the final year, and who came back to complete their studies when more options in the final year became available (papers, projects, examinations in specialized fields), thus pushing up the average study period along with the numbers of 'veterans' who graduated in 1976 or later.

\section{Income levels}

The decision on chosing criteria to measure the success of MBL graduates is complicated by the fact that there is no easy way to define or measure success. Is success determined by income, position, number of subordinates, starting one's own company or total wealth? Consequently it was felt that the most practical way, which admittedly may not be the most scientific, was an analysis of the income levels of the graduates. According to this criterion the MBL graduate is very successful in business.

According to Table 4, the graduates who had completed their studies more than seven years before the survey (Group C), had an average gross income of 
R25 106 in 1978, compared with the graduates who had finished between three and seven years previously (Group B) with R22 546, and those who had finished less than three years before (Group A), with an average gross income of R20 491. Executives and managing directors who constituted $27,6 \%$ of the MBL alumni in the 1978 survey had an average gross income of R26 404 compared with the other group with R20 034.

For the total sample there was almost no difference between the average income of graduates with an engineering background and those with other backgrounds, but a difference arose when the group with an income of above R30 000 was analyzed. This group consisted mainly of engineers.

If the information on the income of MBL graduates is compared with the information on income compiled by the Human Sciences Research Council' in 1977, it can be concluded that the MBL graduate is doing considerably better than the average business manager in South Africa.

In the latter report the median income of a managing director of an average age of 43 was R20 240; the selfemployed executive director (private sector), average age 52, had a median income of R24 750 and general managers, average age 53 , had a median income of R21 150. In 1977 Limerick et al. ${ }^{5, p 7}$ estimated the average income (fringe benefits excluded) for Witwatersrand University MBAs (1970/71 - 1975/76) at R14 940. The average age of the $66 \mathrm{MBA}$ respondents is much lower than that of MBLs.

A comparison was also done between the average incomes of MBL graduates when they started MBL and their income at the beginning of 1978. The MBL-starter salaries for the three groups C, B and A were respectively R9 689, R9 932 and R11 136. The graduates in the three groups increased their salaries respectively by $159,127 \%$ and $80 \%$.

The three groups completed their studies respectively $6,8,4,3$, and 1,5 years before the survey. In South Africa the consumer price index rose by $73,2 \%$ between $1969-$ 1976 (seven years) by $40,8 \%$ between $1972-1976$ (four years) and $26,2 \%$ between $1974-1976$ (two years). Considering the fact that professional salaried businessmen in South Africa experienced a considerable decline in real income during the past seven years, SBL graduates fared exceptionally well as they experienced a sizeable increase in real income. According to Steel and Ward ${ }^{2, p 104}$ MBAs in the United States doubled their starting salaries in about five years. One must agree with Steel and Ward that inflation has also played an important role in the increase in incomes since 1970.

The average gross income of the AEP graduates was found to be slightly lower than that of the MBL graduates - R21 039 for the AEP compared with R21 794 for the MBL. Taking their longer years of business experience into account it is surprising that they earn a lower average gross income than the MBL alumni.

A possible reason is that a large proportion of the AEP respondents in this survey never went to university, i.e. 61 of a total of 139. The average gross income of the AEPs with degrees was R22 141, which is higher than the average gross income of the MBLs. For the AEPs without degrees it was R19 631. This fact, to some extent, indicates the importance of academic qualifications, even in business management.

\section{Income as a function of biographic variables*}

In order to determine the combinations of biographic variables which correlate most closely with income, a multiple regression analysis was carried out. In the case of MBL graduates, more specifically, a step-wise regression analysis was performed. The variables quantified were as follows:

$X_{1}=$ number of subordinates under direct control

$\mathrm{X}_{2}=1$ home language Afrikaans

$\mathrm{x}_{2}=0$ home language not Afrikaans

$\mathrm{x}_{3}=$ age

$X_{4}=$ average mark in final two years of study

$X_{s}=$ income per annum (including all benefits).

It has been found that of the five variables which were included as predictors of income in the step-wise regression analysis, the number of years experience since graduation (variable $\mathrm{X}_{5}$ ) was the single variable which explained the largest proportion of the variance of income. This variable yielded a correlation 0,30 with income and explains $9 \%$ of the variance of income. Steel and Ward ${ }^{2, p 103}$ found a relationship between salary and work experience both before commencing studies and after graduation. Limerick ${ }^{5, p 2}$, in the case of the Witwatersrand Business School, found little difference in later job progress, as reflected by salary of students with or without practical experience. This may be due to the fact that $20 \%$ of his respondents with experience had had only one year of business experience, and to his small sample size (66 respondents). Work experience before graduation was not included as a variable in the SBL calculations. The fact that only $9 \%$ of the variance of the income is explained by experience since graduation, however, strengthens our belief that the success of the SBL may to a large extent be ascribed to the business experience of its students (averaging 10,5 years) before starting with their studies, which is in line with Steel and Ward's results.

It appears that the more subordinates there are under the direct control of the respondent (variable $X_{1}$ ) the greater his income. Respondents whose home language is Afrikaans are associated with a lower income than respondents whose home language is not Afrikaans (variable $\mathrm{X}_{2}$ ).

Income revealed a positive relationship with age (variable $\mathrm{X}_{3}$ ), the average mark obtained during the final two years of study (variable $X_{4}$ ), and the number of years of experience since graduation (variable $\mathbf{X}_{s}$ ).

The combination of all the variables which were included in the final regression equation showed a multiple correlation of 0,45 with income and explained $20 \%$ of the variance in income.

While the above results could have been expected as obvious, the researchers were interested to see in which particular order the set of variables would appear in the proportion of variance, explained singly and in combination.

*In appendix $A$, the means and standard deviations, intercorrelation matrix, stepwise regression analysis with income as dependent variable, are given. 
Another illuminating way to investigate the relationships between income and variables such as average mark, language, and academic background, is to analyze the graduates in the income group above R30 000. In addition the effect of size and type of organization on income level can be considered when this income group is analyzed. Such an analysis is discussed later in this paper.

\section{The managing and executive director group}

Table 4 shows that 84 of the 304 MBLs in the sample $(27,6 \%)$ were managing and executive directors, and that in all $62,1 \%$ were in senior or top management positions. Feldberg ${ }^{3, p 11}$ in his survey of Cape Town MBA graduates $(1966-1976)$ found that $43 \%$ were in top positions (341 responses). Limerick et al. ${ }^{3 . p 4}$ found $20 \%$ of the Witwatersrand MBAs in top management positions and $21 \%$ in senior management positions. The expected relationship between level and income is indicated by the fact that the average income of managing and executive directors was R26 404 compared with R21 794 for the entire group.

Since $69 \%$ of graduates in the top management group are English-speaking (whereas only $61,5 \%$ of the total sample are English-speaking), they appear to be more successful in the business world. This is in keeping with the general picture that, although Afrikaans-speaking South Africans outnumber the English-speaking populace, they have a much smaller share in the total investment in the private sector, and constitutes a smaller percentage of the business world.

The managing and executive director group had a better record than the rest of the graduates in the sample, not only in income but also in the time taken to complete their studies. They are also younger than the average age of the sample; 38,5 years as against a total average of 39,2 .

They attained practically the same mark $(65,0 \%$ as against the total average of $64,5 \%)(67,8 \%$ is equal to A-and $64,5 \%$ to B + in American business schools) but completed the four year MBL programme in a shorter time, 4,7 years as against a total average of 5,3 years. They showed a higher rate of inter-organizational change, that is, $45 \%$ of this group went to work for other companies after graduation compared with $42 \%$ for the sample.

It is also remarkable that the $27,6 \%$ of the total sample who were managing and executive directors, on average attained this level only 3,4 years after graduation. In their survey in the United States, Steel and Ward ${ }^{2, p 100}$ found that MBAs describing themselves as chief executives, increased from $6 \%$ of the total after five years to $37 \%$ in the ensuing 25 years.

\section{The top income level group}

Not all graduates with high incomes are in the managing and executive director group. It is, therefore, necessary to analyze the top income level group on its own. The most successful graduates of the School of Business Leadership could be regarded as those with an income of R30 000 and more and it was found that 43 of 304 MBLs were in this group. Most of them are in senior management positions with an average of 5,2 directorships per person.
Of these 43 MBLs $74 \%$ are English-speaking and $70 \%$ have B.Sc. or other science degrees, mainly in engineering. Twenty-one per cent have BA degrees and only $9 \%$ have a B.Com. or CA, i.e. three graduates of whom two are accountants. Twenty-five of the 43 have changed organizations once and 14 of these more than once. On average they have changed positions 3,8 times. Their inter- and intra-organizational mobility is much higher than the averages for all the respondents.

Steel and Ward ${ }^{2, p 102}$ found that a person's major field in college, MBA major and achievement honours are not at all related to salary levels, with one exception, that is ranking in the top third of the class, which produces a very slight advantage. In the MBL top income level group there seems to be a relation between their financial success and their academic success. Eighteen of them had more than one degree (excluding the MBL degree) and their average mark was $67,8 \%$ compared with $64,5 \%$ for the group as a whole. Another striking characteristic is that nearly $32 \%$ of them were employed in relatively small organizations with fewer than 500 employees (or in organizations which were small when they joined them).

Furthermore, $28 \%$ of this group was employed by consulting organizations or were in professional positions, and $47 \%$ in manufacturing. The results of the analysis of the top income group support the conclusions in the two previous sections. The level of management, mark, home language, and academic background explain an important percentage of the variations in income of alumni. Variables not mentioned before but which seem to play a role are the preponderance of highly successful alumni in small organizations and in consulting and professional positions.

\section{Distribution and mobility of MBA graduates}

In studies done in the United States and the United Kingdom it was found that while MBA graduates would prefer to work in small organizations most of them joined large ones. This raises the question whether this factor may not be the reason why many leave soon afterwards. There is also a relationship between those who changed their jobs and those who launched their own businesses. Steel and Ward ${ }^{2, p 104}$ found that of graduates who had completed their studies 15 or more years before their survey, nearly $25 \%$ who had changed companies within 2 to 5 years after graduation eventually started their own businesses. Steel and Ward ${ }^{2, p 106}$ also found that MBAs joining large organizations increasingly prefer large companies in which decentralization is pronounced. This indicates the desire to be in smaller decision-making units where a manager is responsible for more general policy matters compared with the specialized type of decisionmaking to be found in the head offices of large organizations. In the United Kingdom the British Institute of Management ${ }^{4, p 2}$ also found that graduates tend to move to smaller companies. With the above tendencies it is understandable that there is a great deal of mobility from one industry or firm into another. What is the magnitude of the inter-organizational mobility? Steel and Ward found that turnover within the first five years ran between $40 \%$ and $45 \%$. In 1977 Feldberg $^{3, p 17}$ found that nearly $70 \%$ of his Cape Town graduates of 1966-1968 and 1969-1970 had changed jobs, about $55 \%$ of the 
$1971 / 1972$ class and $45 \%$ of the $1973 / 1974$ class. Limerick et al. ${ }^{5, p^{4}}$ found that in the case of Witwatersrand MBAs $50 \%$ changed their jobs over an average four year period.

In addition to inter-organizational movements there are also intra-organizational movements which usually indicate occupational or positional mobility within the same firm, e.g. change from specialist and functional to general management. Concerning intra-organizational mobility or occupational mobility between line and staff in the United States, it is pointed out that MBAs found it difficult to classify their jobs as distinctly line or distinctly staff, although in the case of MBAs it has been said that MBAs are mostly trained for, and are more at home in, staff jobs. Steel and Ward ${ }^{2, p 106}$ found 36\% MBAs who had finished in 1969 in staff jobs compared with $22 \%$ who had finished in 1947. The opposite trend is to be found with graduates who are mainly in line positions, i.e. a decrease over the years. The British Institute of Management ${ }^{4 . p 3}$ summarized inter- and intraorganizational mobility in the United Kingdom as a drift away from manufacturing, the production function and large companies to smaller companies, to selfemployment and to general management. Industry change (inter-industry mobility) has taken place to banking, consulting and teaching. What is the position with regard to intra- and inter-organizational and interindustry mobility with the MBL graduate who has a somewhat different background from the MBA graduate? MBLs are generally older than the average MBA student, have more business experience and study part-time, which must have an effect on their mobilities.

\section{Inter-organizational change of MBL graduates}

The result of the 1978 survey (Table 4) was an average inter-organizational change figure of 0,424 or $42 \%$ which indicates the stability of MBL graduates - $58 \%$ have not changed their organizations. This means $62,5 \%$ of Group

Table 5 Industry analysis of employment of MBL graduates and MBL students

\begin{tabular}{|c|c|c|c|}
\hline & $\begin{array}{c}\text { MBL } \\
\text { graduates } \\
1973 \\
\text { survey } \\
\% 0\end{array}$ & $\begin{array}{c}\text { MBL } \\
\text { graduates } \\
1978 \\
\text { survey }^{2} \\
\%\end{array}$ & $\begin{array}{c}\text { MBL } \\
\text { students } \\
1977 \\
\%\end{array}$ \\
\hline $\begin{array}{l}\text { Financial institutions and } \\
\text { mining houses }\end{array}$ & 5,6 & 7,9 & 6,0 \\
\hline Manufacturing & 55,6 & 38,6 & 46,0 \\
\hline Public corporations $^{3}$ & - & 6,9 & 12,0 \\
\hline Commerce & 5,6 & 4,5 & 11,0 \\
\hline $\begin{array}{l}\text { Civil service and semi- } \\
\text { government bodies }\end{array}$ & 2,8 & 8,3 & 8,0 \\
\hline Service and consulting & 19,3 & 20,0 & - \\
\hline Agriculture and co-ops & 2,8 & 5,9 & 4,0 \\
\hline Mining and construction & 8,3 & 7,9 & 13,0 \\
\hline Total & 100,0 & 100,0 & 100,0 \\
\hline
\end{tabular}

${ }^{1}$ Includes MBL graduates $1968-1972$.

${ }^{2}$ Includes MBL graduates $1968-1977$.

${ }^{3}$ In 1973 employment in Public Corporations was included under manufacturing.
A, $47,4 \%$ of Group B and $55,8 \%$ of Group C have not changed employers. The change figure for the managing directors and top executives is $45,3 \%$ and $39,2 \%$ for engineers. The top executives show a higher interorganizational mobility rate than the engineers.

\section{Inter-industry change and comparison}

An analysis of MBLs according to industry is given in Table 5.

Although the classification for the three groups in Table 5 is not precisely the same, there appears to be a movement away from manufacturing, if employment in manufacturing (including public corporations) is compared between MBL students and MBL graduates. In $197758 \%$ of the MBL students were in this group compared with $55,6 \%$ for the alumni in 1973 and $45,5 \%$ in 1978. There is an indication of a movement into services, professional positions and consulting because $20 \%$ of the 1978 alumni were in this field whereas in the case of 1977 MBL students the numbers were not significant enough to be classified separately. In analyzing the alumni in this latter employment group, $33 \%$ were in organizations with fewer than 10 people and $52 \%$ in organizations with fewer than 50 people. Feldberg ${ }^{3 . p 3}$ found that $18 \%$ of all Cape Town MBAs occupied professional positions in law, accounting and consulting and Limerick et al ${ }^{\text {s.p4 }}$ that in the case of Witwatersrand MBAs, $9 \%$ were in consulting and professional positions. Again Limerick's respondents were much younger than those of Cape Town and the SBL. The information in Table 5 corresponds closely with the information collected by Feldberg ${ }^{3 . p 9}$ for Cape Town MBAs, namely 36\% for manufacturing and $23 \%$ for services. If public corporations are added to manufaturing, MBLs are more concentrated in manufacturing $(45,5 \%)$ than the Cape Town MBAs. Limerick et al. ${ }^{5 . p 3}$ found $45 \%$ of the Witwatersrand MBAs in manufacturing. The MBLs differ from Cape Town MBAs with regard to: commerce; $4,4 \%$ for MBLs and 18\% for MBAs; mining; 7,1\% for MBLs and $4 \%$ for MBAs; and government: $8,2 \%$ for MBLs and 5\% for MBAs. Witwatersrand corresponds with Cape Town with regard to commerce, $(16 \%)$ and with the SBL with regard to mining $(9 \%)$. Thus the MBL differs from the other business schools with regard to percentage employment in commerce, and government; and in agriculture which the other schools do not even mention; corresponds with them with regard to financial institutions and manufacturing; corresponds with Cape Town with regard to consulting and with Witwatersrand with regard to mining.

The British Institute of Management ${ }^{4}$ found $43,6 \%$ of the MBAs in manufacturing, $14,1 \%$ in banking, $9,5 \%$ in consulting and $9,3 \%$ in teaching. In the case of the SBL, banks apparently rather send their managers on the executive programme than on the MBL.

Inter-organizational mobility to small organizations Table 6 shows an analysis of the size of the organizations employing MBLs. It is clear from Table 6 that a large percentage of the MBLs were employed in small organizations (under 500 employees). In 1973 it was $43,6 \%$ and in 1978 it was $42,9 \%$.

The large number of MBLs employed in organizations 
Table 6 Employment of MBL graduates according to size of organization

\begin{tabular}{lcrr}
\hline No. of employees & $\begin{array}{c}1978 \\
\text { survey } \\
\%\end{array}$ & $\begin{array}{c}1973 \\
\text { survey } \\
\%\end{array}$ \\
\hline Below 100 & & 19,3 & 20,5 \\
& $100-200$ & 10,3 & 7,4 \\
& $201-300$ & 7,3 & 5,0 \\
& $301-500$ & 6,0 & 10,7 \\
& $501-1000$ & 14,6 & 18,8 \\
& $1001-2000$ & 15,3 & 10,6 \\
Above 2000 & 27,2 & 27,0 \\
Total & 100,0 & 100,0 \\
\hline
\end{tabular}

with fewer than 100 employees, agrees with the result mentioned before, that is the increasing number of MBLs moving to service industries and consulting after graduation.

In many cases the movement was into consulting in production and project management, property and finance. The movement corresponds with trends overseas.

\section{Functional position and intra-organizational mobility}

Intra-organization mobility is indicated by the occupational change figure, movement between line and staff and movement between functions within one organization. According to the 1978 survey, the occupational change figure is on average 1,81 or $181 \%$. The positional changes usually indicate upward movement in the organization. As expected the occupational or positional change figure is lower than average for Group A, at 1,73, and higher for Group $C$, at 1,96, due to the years after completion of the MBL. For managing and executive directors it is $189 \%$. There is very little difference in the occupational change figure between those with engineering and scientific backgrounds and those with other degrees, 180 and $182 \%$.

In the case of functional mobility, the British figure indicates a high movement away from production to general management. In the BIM report ${ }^{4 . p^{2}}$ it is stated that $17 \%$ of the business graduates were in production before going to business schools, but only $6 \%$ returned to production afterwards. Only 3\% of the sample in the BIM report were in production when the survey was completed. The functions in which the highest proportions of business graduates were found are general management $(12,8 \%)$, finance $(35 \%)$ and marketing $(19,5 \%)$. Feldberg ${ }^{3 . p 8}$ found that $23 \%$ of his alumni were in general management/administration, $7 \%$ in planning, $7 \%$ in consulting, $8 \%$ in production, $13 \%$ in marketing, $16 \%$ in finance and $24 \%$ in other functions. The 1978 survey of MBLs shows the same tendency as the BIM report, namely a movement away from production.

Group $A$, the younger age group, had $41,5 \%$ of the MBLs in production compared with $26,9 \%$ of the (older) $\mathrm{C}$ group. If the positions on registration of the MBL graduates in the 1978 survey are analyzed, $20,4 \%$ were in production; $42,5 \%$ stated that they were in engineering (electrical, mechanical, civil, chemical, etc.) or other pro- fessions, and thus probably directly or indirectly involved in production; $4,1 \%$ were consultants, $7,9 \%$ in marketing, $7,5 \%$ in finance, and $17,6 \%$ managers of branches, divisions, companies or factories.

The original occupational distribution of MBL graduates corresponds with their academic backgrounds, i.e. $56,2 \%$ B.Sc. (including engineering); $21,6 \%$ Honours and Master's degrees (mainly in a science field); $10,5 \%$ B.Com, and 5,5\% BA.

In 1978, on average 3,1 years after graduation, there were 27,6\% Managing and Executive Directors; $34,9 \%$ were in production; $11,8 \%$ were in marketing; $6,6 \%$ were in finance; $7,6 \%$ were in the academic world; $6,3 \%$ were in administration and $5,2 \%$ were in other positions. If the 43 graduates with an income above $R 30000$ are analyzed it is found that when they started the MBL $34,9 \%$ were branch, division or factory managers; $18,6 \%$ in marketing; $11,6 \%$ in production and 11,69 stated thatthey were engineers.

Taking the preponderance of scientific and technical backgrounds of the respondents into account, it is understandable that most of them were in production. A noteworthy statistic shows that $12,1 \%$ of the MBLs had previous master's degrees, and they contributed $20,2 \%$ to the group of managing directors and general managers. Between the three groups A, B and C there was very little difference in academic backgrounds.

\section{The SBL image}

A series of bi-polar adjectives were listed opposite a five point scale to attain the personal opinion of alumni regarding the image of the SBL. The results are given in Table 7 according to which the MBL graduates rate the school as relatively progressive, modern, practical, helpful, inexpensive and informal.

Table 7 also indicates that the SBL will have to pay more attention to publicity to advertise itself because the alumni are of opinion that it is not very well known. There is also the problem of efficiency which has declined in rating if groups $A$ and $C$ are compared.

An organization working with career-involved businessmen must maintain a certain flexibility with regard to the submission of assignments, which affects efficiency of the school's administration. With the rapid increase in the size of the school the increase in administrative staff has lagged in relation to the increase in academic staff and in the number of students. This has contributed to the decline in the efficiency image.

\section{Conclusion}

One can conclude that the graduates of the SBL play a leading role in the South African business world. They are among the highest paid businessmen in South Africa and show a relatively low rate of inter-organizational change but a high intra-organizational and upward change rate. In the case of the inter-organizational change there seems to be a movement towards small organizations, especially consulting concerns and a movement away from manufacturing and large organizations. With regard to intra-organizational mobility there is a movement from production to general management.

In a very short period, $62 \%$ of the graduates attained senior management positions, and $27,6 \%$ were managing 
Table 7 The image of the School of Business Leadership. Average rate values on a scale 1:5'

\begin{tabular}{lccc}
\hline & \multicolumn{3}{c}{ MBL } \\
& \multicolumn{3}{c}{ Years after completion } \\
\cline { 2 - 4 } & A & B & C \\
& $0-3$ & $4-6$ & more \\
& years & years & years \\
\hline Progressive/Unprogressive & 1,77 & 1,66 & 1,75 \\
Efficient/Inefficient & 3,01 & 2,57 & 2,35 \\
Dynamic/Static & 2,04 & 1,92 & 1,96 \\
Modern/Old-fashioned & 1,97 & 1,71 & 1,83 \\
Effective/Ineffective & 2,32 & 2,07 & 2,06 \\
Theoretical/Practical & 3,12 & 2,91 & 3,02 \\
Well-known/Little known & 2,82 & 2,83 & 2,58 \\
Helpful/Unhelpful & 2,07 & 1,86 & 1,90 \\
Expensive/Inexpensive & 3,17 & 3,24 & 3,31 \\
Afrikaans/English ${ }^{2}$ & 2,99 & 3,13 & 2,87 \\
Reliable/Unreliable & 2,55 & 2,17 & 2,17 \\
Superior to MBA/Inferior to MBA & & & \\
(SA) & 2,08 & 1,88 & 2,17 \\
Imaginative/Unimaginative & 2,21 & 2,08 & 2,25 \\
Active/Passive & 2,17 & 1,96 & 2,04 \\
Attractive/Unattractive & 2,34 & 2,26 & 2,27 \\
Thorough/Negligent & 2,77 & 2,41 & 2,33 \\
Formal/Informal & 3,53 & 3,39 & 3,35 \\
Conscientious/Careless & 2,53 & 2,32 & 2,21 \\
\hline & & & \\
\hline & & &
\end{tabular}

'Below 2,5 is in favour of the adjective to the left and above 2,5 to the right of the bi-polar.

${ }^{2}$ The SBL teaches in the two official languages of South Africa. In the classroom both languages are used and students come from both language groups.

and executive directors. There appears to be a close relationship between the success of graduates if this is measured by the increase in their incomes and their level in the organization, and the average mark obtained during the last two years of study, academic backgrounds and their home language.

Many of the MBL graduates in top management positions have more than one degree besides the MBL and their average mark during the last two years of study was higher than the average for the total group. Finally, the graduates regard the SBL as being progressive, modern, practical, helpful, inexpensive and informal but they would like more publicity and higher administrative efficiency. It seems that our results are in agreement with those of Steel and Ward in concluding that practical experience before studying management has a positive effect on the later success of the students. By satisfying the needs of the mature and experienced executive, the story of the School of Business Leadership with its unique tPaining system has been a success story.

\section{Acknowledgements}

The author was assisted by Professor P.L.S. Ackermann and Mr E.D. Schmikl of the School for Business Leadership, who were responsible for the surveys done and the multiple regression analyses.

\section{References}

1 DE KLERK, D. The wage structure of highly qualified white men as at I March 1977. South African Human Sciences Research Council, Pretoria, (Research Finding M-N-48), 1977.

2 STEELE, J.E. \& WARD, L.B. MBA mobile, well situated, well paid; a survey of some 6000 alumni of 16 schools. Harv. Bus. Rev., pp. $99-110,1974$.

3 FELDBERG, M. The MBA graduate; a profile of Cape Town's MBA graduates, 1966 - 1976. Graduate School of Business, University of Cape Town, 1977

4 BRITISH INSTITUTE OF MANAGEMENT. Business graduates in industry. Current Issue Occasional Paper, New Series OPN 13, 1974.

5 LIMERICK, D.C., BUSS, J.H., BROWN, D.J. \& TABACHNICK, M. A selected profile of the University of the Witwatersrand Business School Graduate and his impressions of some facets of the Wits MBA Programme, Johannesburg. Graduate School of Business Administration, University of the Witwatersrand, Opinion Papers, No. 5, 1977.

\section{Appendix A}

\section{Income as a function of blographic variables}

In Table 1 the means and standard deviations of the various variables are displayed.

\section{Table 1 Means and standard deviations}

\begin{tabular}{|c|c|c|c|}
\hline & Variable & $\mathbf{x}$ & $\mathbf{S}$ \\
\hline$\overline{X_{1}=}$ & $\begin{array}{l}\text { number of subordinates } \\
\text { under direct control }\end{array}$ & 88,09 & 309,64 \\
\hline$x_{2}=$ & home language & 0,43 & 0,50 \\
\hline$x_{3}=$ & age & 39,04 & 7,05 \\
\hline$x_{4}=$ & $\begin{array}{l}\text { average mark in final } \\
\text { two years of study }\end{array}$ & 64,52 & 8,78 \\
\hline$x_{5}=$ & $\begin{array}{l}\text { years of experience } \\
\text { since graduation }\end{array}$ & 3,10 & 2,55 \\
\hline $\mathbf{Y}=$ & income per annum & R21 794,40 & 27343,51 \\
\hline
\end{tabular}

Table 2 reflects an intercorrelation matrix of the various variables under examination.

Table 2 Intercorrelation matrix of all the variables

\begin{tabular}{ccccccc}
\hline Variable & $\mathrm{Y}$ & $\mathrm{X}_{1}$ & $\mathrm{X}_{2}$ & $\mathrm{X}_{3}$ & $\mathrm{X}_{4}$ & $\mathrm{X}_{3}$ \\
\hline $\mathrm{Y}$ & 1,00 & 0,16 & $-0,16$ & 0,12 & 0,23 & 0,30 \\
$\mathrm{X}_{1}$ & & 1,00 & 0,04 & 0,00 & 0,03 & 0,12 \\
$\mathrm{X}_{2}$ & & & 1,00 & 0,08 & $-0,14$ & 0,07 \\
$\mathrm{X}_{3}$ & & & & 1,00 & $-0,04$ & 0,19 \\
$\mathrm{X}_{4}$ & & & & & 1,00 & $-0,08$ \\
$\mathrm{X}_{5}$ & & & & & & 1,00
\end{tabular}

Correlation coefficient $-0,15$ is significant at 0,01 level.

Correlation coefficient $-0,11$ is significant at 0,05 level.

From Table 2, variable $X_{s}$ (number of years of experience since graduation) emerged as the variable having the highest correlation $(0,30)$ with the dependent variable, income. Variable $\mathrm{X}_{4}$ (the average mark obtained during the final two years of study) has the second highest correlation with income. As can be seen from the Table, all the remaining independent variables reveal a significant correlation with income.

In Table 3 the standard error of estimate, the multiple correlation, and the proportion variance, explained at each step of the step-wise regression analysis, are tabulated. 
Table 3 Step-wise regression analysis with income as dependent variable

\begin{tabular}{lccc}
\hline Step variable selected & $\begin{array}{c}\text { Standard } \\
\text { error of } \\
\text { estimate }\end{array}$ & $\begin{array}{c}\text { Multiple } \\
\text { correlation } \\
\text { (R) }\end{array}$ & $\begin{array}{c}\text { Proportion } \\
\text { variance } \\
\text { explained (R }\end{array}$ \\
\hline $1 \mathrm{X}_{5}$ & 7028,37 & 0,30 & 0,09 \\
$2 \mathrm{X}_{5}, \mathrm{X}_{4}$ & 6788,86 & 0,39 & 0,15 \\
$3 \mathrm{X}_{5}, \mathrm{X}_{4}, \mathrm{X}_{1}$ & 6709,30 & 0,42 & 0,18 \\
$4 \mathrm{X}_{5}, \mathrm{X}_{4}, \mathrm{X}_{1}, \mathrm{X}_{2}$ & 6622,32 & 0,44 & 0,19 \\
$5 \mathrm{X}_{5}, \mathrm{X}_{4}, \mathrm{X}_{1}, \mathrm{X}_{2}, \mathrm{X}_{3}$ & 6607,71 & 0,45 & 0,20 \\
\hline
\end{tabular}

The following variables were selected in sequence: years of experience since graduation $\left(\mathrm{X}_{s}\right)$, the average mark obtained during the final two years of study $\left(X_{4}\right)$, the number of subordinates under direct control $\left(X_{1}\right)$, home language $\left(X_{2}\right)$, and age $\left(X_{3}\right)$.

The regression coefficients, standard error of the regression coefficients, F-values for determining the significance of the regression coefficients, and the constant term are shown in Table 4.

Table 4 Step-wise regression analysis with income as dependent variable

\begin{tabular}{crrc}
\hline Variable & $\begin{array}{l}\text { Regression } \\
\text { coefficient }\end{array}$ & \multicolumn{1}{c}{$\begin{array}{c}\text { Standard } \\
\text { error }\end{array}$} & \multicolumn{1}{c}{ F-value } \\
\hline$X_{1}$ & 3,75 & 1,23 & $9,300,001$ \\
$X_{2}$ & $-2402,99$ & 777,21 & $9,560,001$ \\
$X_{3}$ & 83,85 & 55,00 & $2,320,05$ \\
$X_{4}$ & 192,04 & 43,80 & $19,220,001$ \\
$X_{5}$ & 882,57 & 152,31 & $33,580,001$
\end{tabular}

Constant term $=4100,99$.

The negative coefficient in Table 4 can be ascribed to the method in which the variable was quantified. As the quantification was carried out arbitrarily, the quantification of the home language could also have been done as follows;

$X_{2}=1$ home language English or foreign languages $=0$ home language Afrikaans.

In that case the particular regression coefficient would have been positive.

From Table 4, the following regression equation for the prediction of income is derived:

$\hat{Y}=4100,99+3,75 X_{1}-2402,99 X_{2}+83,85 X_{3}+$ $192,04 X_{4}+881,57 X_{5}$, where $\hat{Y}$ is the predicted value of income, the constant term being 4100,99 and $X_{i}$ as defined, and the multipliers are the regression coefficients.

It is apparent from this investigation that only $20 \%$ of the variance of income has been explained by the variables selected and that the standard error of estimate is particularly large. A large proportion, namely $80 \%$, of the variance of income has not been explained by these variables. In the view of these circumstances, the limitation of the results of this investigation for the prediction of income must be realized. 